\title{
A study of student and teacher attitudes and experiences towards an immersion course in a Technological University in Veracruz, Mexico
}

\section{Un estudio acerca de las actitudes y experiencias de maestros y alumnos en un curso de inmersión en una Universidad Tecnológica en Veracruz, México}

\author{
BARRAGÁN-DÍAZ, Julian*† \\ Universidad Tecnológica de Gutiérrez Zamora
}

ID $1^{\text {st }}$ Author: Julian, Barragán-Díaz / ORC ID: 0000-0002-9582-1762

DOI: $10.35429 / J T E R .2019 .16 .5 .20 .34$

Received September 02, 2019; Accepted December 30, 2019

\begin{abstract}
Mexico is experiencing a growing need of qualified professionals able to work and receive training in international companies. For this reason, education authorities in Mexico have created technological universities and, in recent years, a new model for them called BIS model (Bilingual, International and Sustainable). It is a bilingual model which starts with an immersion course followed by a bilingual program whose objective is to graduate technicians and engineers with a high level of English language proficiency. This research intended to study the attitudes and experiences of students and teachers who participated in an immersion course in a BIS model university in Veracruz, Mexico to identify the attitudes of both students and teachers towards the course to help designing future courses to avoid potential language learning problems related to attitudinal and motivational factors. In order to do this, quantitative and qualitative paradigms were used through the application of questionnaires and semi-structured interviews to sixty-five students and teachers as well as class observations. The results showed that while students and teachers generally had a positive attitude towards the program, there are a number of factors that affected their performance such as the students' profile, their motivations to study the language, their motivations to study a bilingual program and the course planning.
\end{abstract}

Teaching, Attitudes, Immersion

\begin{abstract}
Resumen
México está experimentando una creciente necesidad de profesionales calificados que puedan trabajar y recibir capacitación en compañías internacionales. Por ésta razón las autoridades mexicanas han creado universidades tecnológicas y, en años recientes, un nuevo modelo para ellas llamado BIS (Bilingüe, Internacional y Sustentable). Éste es un modelo bilingüe que incluye de inicio un curso de inmersión seguido de un programa bilingüe cuyo objetivo es graduar técnicos e ingenieros con un alto nivel de dominio del idioma inglés. Ésta investigación busca estudiar las actitudes y experiencias de alumnos y maestros que participaron en el curso de inmersión en una universidad BIS en Veracruz, México para identificar las actitudes de ambos durante el curso y así ayudar a diseñar cursos que eviten problemas en la enseñanza del inglés relacionados con cuestiones actitudinales. Para esto se utilizaron paradigmas cualitativos y cuantitativos por medio de la aplicación de cuestionarios y entrevistas semiestructuradas a sesenta y cinco participantes así como observaciones de clases. Los resultados encontrados muestran que, aunque alumnos y maestros tuvieron en general una actitud positiva con respecto al programa, existió un número de factores que afectaron su desempeño tales como: el perfil de los alumnos, sus motivos personales para estudiar el idioma, sus motivos personales para estudiar un programa bilingüe y la planeación del curso.
\end{abstract}

Enseñanza, Actitudes, Inmersión

Citation: BARRAGÁN-DÍAZ, Julian. A study of student and teacher attitudes and experiences towards an immersion course in a Technological University in Veracruz, Mexico. Journal of Teaching and Educational Research. 2019. 5-16: 20-34

\footnotetext{
* Correspondence to the Author: (julian.barragan@utgz.edu.mx)

$\dagger$ Researcher contributing as first Author
} 


\section{Introduction}

The need to provide the working sector with qualified labor able to communicate with workers from other nationalities has led the government of Mexico to implement programs for the teaching of English from elementary school to high school. Unfortunately, these efforts have not been successful enough to develop the communicative skills of the students since, as in the case of the place where the researcher works, most of the students that start undergraduate programs have an A1 or A2 level according to the Common European Framework of Reference (CEFR). After completing high school Mexican students have different options to start undergraduate programs.

One of the options that have gained relevance is the subsystem of Technological Universities across Mexico. This type of Universities bear a resemblance to colleges around the world since they offer technical and engineering degrees aimed at satisfying the needs of the companies in the area in which each university is located. In later years changes have been made to the format of delivering some courses of the already established programs, these changes are related to the implementation of bilingual education and immersion courses inside the curriculum; this new model of Technological Universities is called BIS (Bilingual, International and Sustainable).

The objectives of these new types of programs are communicated to students and often touched in discussions and it is common to hear comments from some students feeling stressed about reaching the level required to start the bilingual program (level A2). This situation raised my interest on studying which aspects come into play when students are learning English in an immersion program to form their attitudes towards learning as well as the teacher's perspectives on such phenomenon. The researcher considers this is important to my community since doing a research of the attitudes and experiences of the participants in an immersion program can be helpful when designing new courses that take into consideration the specific context of this university. The researcher has worked in this University for some years and has observed a pattern of low interest from the students to learn a second language which may have been a factor that affected some of these students' grades.
However, the new bilingual model is more demanding and creates a situation that may turn difficult for students with negative attitudes toward learning English because it can represent an obstacle between them and their goals of studying in a bilingual university. It was the purpose of this study to identify the attitudes of both students and teachers towards immersion programs, to study the experiences of both students and teachers in an immersion program from September 2016 to December 2016, and to help improving the design of future courses to avoid potential language learning problems related to attitudinal and motivational issues.

\section{Immersion Programs}

Lyster (in Cammarata and Tedick, 2012:252) provides a definition of what immersion is, he definies as:

'a form of bilingual education that aims for additive bilingualism by providing students with a sheltered classroom environment in which they receive at least half of their subject-matter instruction through the medium of a language that they are learning as a second, foreign, heritage, or indigenous language. In addition, they receive some instruction through the medium of (the majority language) in the community.'

This definition constitutes the basis on which immersion programs are developed.

Immersion programs were originated in Canada in the 1960s when parents detected the need of their children for learning French due to the fact that the English-speaking community in Quebec noted this language was needed in a region which predominantly used French in their daily lives. Scholars of bilingualism at McGill University were reached by parents and worked in developing a new program which was characterized by the use of the target language as a means of instruction since the first day of school in kindergarden. It was planned first to focus on acquiring reading skills before introducing other subjects in later grades, in this way by grade 6 half the curriculum was taught in French and half was taught in English; this program was known as the St. Lambert experiment (Lambert \& Tucker in Cammarata and Tedick, 2012) or the St. Lambert program. 
According to studies on immersion education from the California State Department of Education $(1984: 11)$ the concept of immersion schooling was based on a fundamental premise:

'... people learn a second (or third) language in the same way as they learn their first; that is, in contexts where they are exposed to it in its natural form and where they are socially motivated to communicate'

These studies also point out differences between immersion programs and other two common types of instruction, by means of doing a comparison it is possible to have a clearer view of the nature of immersion programs. First, the difference between immersion programs and second language teaching programs is mentioned and it states that the objective of the first is the mastery of the subject matter and thus not much time is dedicated to language teaching since it becomes a responsibility of a language expert, not the professional who is teaching a subject not related to language teaching. Second, the difference between immersion programs and bilingual programs is that, in the first, bilingualism is achieved through two different channels, this is, each instructor serves as a 'monolingual instructional route' who never switches between language or uses any instructional material in both languages compared to an instructor from a bilingual program who is able to use special material for the purpose of learning contents in a second language or developing language skills.

It is pertinent to mention the core feature of immersion programs mentioned by Johnson and Swain in Cummins (2000):

1. The L2 is a medium of instruction

2. The immersion curriculum parallels the local L1 curriculum

3. Overt support exists for the L1

4. The program aims for additive bilingualism

5. Exposure to the L2 is largely confined to the classroom

6. Students enter with similar (and limited) levels of L2 proficiency

7. The teachers are bilingual

8. The classroom culture is that of the local L1 community

\section{Bilingualism and Bilingual Education}

As it was mentioned before, the objectives of Immersion programs are to help promote bilingualism and biliteracy. According to Bathia and Ritchie (2006:8) 'earlier definitions tended to restrict bilingualism to equal mastery of two languages, while later ones have allowed much greater variation in competence'. The authors also mention that, nowadays, all discussions related to his need to take into account both a specific context as well as specific purposes. Baker (2001) starts by stating the differences between bilingualism as 'an individual characteristic and bilingualism in a social group, region or country', this is, as an individual possession (individual bilingualism) or as a group possession (societal bilingualism).

The author mentions that although a person may be able to speak two languages it is common to use just one language in practice or that competence in one language is limited; for this reason it is important to establish the difference between language ability and language use, sometimes mentioned as the difference between degree and function.

Some other considerations to take into account relate to the classification of bilinguals such as the one suggested by Valdés and Figueroa in Baker (2001), he suggest that bilinguals are classified by:

Age - It plays a role when defining the type of bilingualism acquired: simultaneous, sequential or late. Simultaneous bilingualism occurs when two languages are learned at the same time such being the case of children parents with different languages. Sequential bilingualism refers to when a child learns the second language after learning much of his first and finally, late bilingualism is when an individual learns a second language after the age of 6 or 7 Ability (incipient/receptive/productive). Balance of two languages.

Development. Ascendant if second language is developing and recessive in case one language is decreasing).

Contexts where each language is acquired and used (for instance home, school). 
Circumstantial bilingualism
individuals whose role in society
requires them to learn a second
language).

- $\quad$ Elective bilingualism (those individuals who choose to learn a second language to satisfy certain needs).

One of the most important concepts in bilingual education is biliteracy which in the 1970s 'carried connotations of fluency and mastery of in the reading and writing of two or more languages' Hornberger in Vaish (2008). However, Hornberg gave her own definition stating that 'any and all instances in which communication occurs in two (or more) languages in or around writing'. In this sense it is important to point out the relation between biliteracy and some of the immersion programs discussed earlier as Cammarata and Tedick (2012) state: 'The principal aims of both Oneway and Two-way immersion programsare to promote additive bilingualism and biliteracy, academic achievement and cultural understanding.

These concepts are also mentioned by Baker (2001), he claims that the aim in language outcome of the immersion programs are bilingualism and biliteracy as well as achieving pluralism and enrichment of the society. Previous to this, Baker (in Roberts 1995) had classified the goals of bilingual education into national or societal goals, linguistic goals, and educational goals.

\section{Common European Framework of Reference}

The Common European Framework of Reference (CEFR) is a common basis developed by the Council of Europe to provide help in the elaboration of language syllabuses, curriculum guidelines, examinations, textbooks, etc. by means of describing what learners have to learn and do in order to communicate and act effectively (Council of Europe, 2001).

In order to help learners and users of languages six levels were developed: Breakthrough, Waystage, Threshold, Vantage, Effective Operational Proficiency and Mastery; these levels can be visualized into three broad levels that cover from Basic User, Independent User to Proficient User (Figure 1).
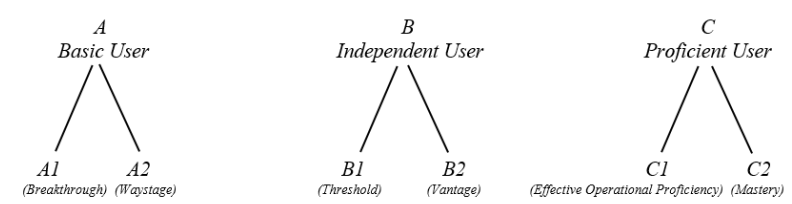

Figure 1 Common reference levels

\section{Attitudes in Language Learning}

Brown (2000) mentioned that attitudes are have their origins in early childhood and are an aspect of the development of cognition, thus are a result of two aspects, one being the parents' and peers' attitudes towards people who are 'different' and the other the interacting affective factors in the human experience. Brown also claimed that attitudes can have an impact on language learning; students benefit from positive attitudes opposite to negative attitudes which may lead to demotivation and, due to the lack of input and interaction, students could be unsuccessful when trying to attain proficiency. Also, Kara (2009) mentioned that some studies have investigated the effects of attitudes toward learning and have found that attitudes were 'more significant predictors of academic success rather than university entrance examinations'.

Attitudes and their relation to success is also mentioned by Kara in some studies whose results have shown that students who believe the contents seen in classes are relevant to their selfdevelopment and their future work harder; they are more willing to learn contents if the information is congruent with real life. Other aspects mentioned by Kara are that other results from researchers such as Tsai \& Kuo who found that 'students' willingness to learn stemmed from a fear of getting low marks and that they defined learning as memorising information, preparing for tests, solving problems and calculating'.

This seems related to what Zainol (2012) is concerned about; he questions about some EFL students getting higher grades in English in spite of being examined under the same conditions. He states that Gardner in 1985 emphasized his concern about attitudes toward the target language and how these attitudes play a key role in motivating student to learn it affecting their performance in the language. It will be discussed later if this holds true for the participants of this study. 
Finally, Cook (2008) mentions there is a relation between the attitudes towards other cultures and how teaching can reinforce unfavorable images of L2 users. She states that coursebooks normally show only two types of language users: students or native speakers but do not include successful or famous L2 users. Cook considers this reflection important because changing people's attitudes is one of the goals of language teaching. Robert Gardner in Cook (2008) also mentions there is a close relation between attitudes and success in language learning in his view of L2 learning.

In his proposed socio-educational model, he explained how individual factors and general features of the society interact in L2 learning; he mentions that two of the components for learners' success are motivation and ability and mentions the two factors of motivation: a) attitudes to the language situation which refer to the teacher and the course and b) integrativeness which is a combination of factors about how the learner perceives the culture reflected in the second language; both of these factors can be found, according to Gardner, in the educational setting and cultural context within which the students are placed.

\section{Methodology}

This research was conducted in the Technological University of Gutierrez Zamora, located in the southeastern state of Veracruz. In September 2016 the BIS (Bilingual, International and Sustainable) model was opened for those students interested in receiving professional bilingual education.

The participants in this study are sixtyfive students, they are young adults from 18 to 20 years old enrolled in the 525-hour English immersion course required to start the first trimester in the bilingual model of the university. Most of the students had previously studied English in public high schools where ESL contents cover topics from beginner to intermediate level, however it is common to observe that most students finish high school with a low level of English. Besides, their contact with the English language is limited due to a number of factors, one being the dominance of monolingual speakers in the zone and the difficulty to interact with native speakers.
Other is the location since the university operates in a small town 1 hour and 45 minutes away from the nearest city and, as a consequence, many students come from other small towns with limited access to mass media such as cinema or even Internet.

Having groups of students with these characteristics made necessary the application of a test to have information about their level of English at the beginning of the immersion course. Moreover, a small group of five English teachers who were teaching during the immersion course also participated, they are professionals with a BA in Language Teaching and some years of experience, however it was their first time teaching an immersion course for preparing students for a bilingual program.

Carrying out a research may involve working with two paradigms; quantitative and qualitative, and while the first is more oriented to the scientific tradition, it is the second which is reflective or experiential in nature (Davies \& Hughes, 2014). There are many attempts at defining what qualitative research is, however it is not a definition what look for in this study but the characteristics that may help the researcher achieve the goals mentioned above. The objective of this research is not to obtain statistics or figures of grades or frequency of opinions at the end of the study, instead, it intends to have a better picture of the phenomena occurring in specific language classrooms in the university and hopefully identify new issues for further studies. Although a qualitative paradigm is used throughout the research, some procedures were used to gather quantitative data such as questionnaires and their analysis.

Prior the start of the immersion course, the institution required the students present an entrance exam to know the level of English proficiency they had. Such exam measured their level up to an A2 level. At the end of the course a final exam (also an A2 exam) was applied to have information about the progression of the students' English level. In this study such data will be used to have a clearer view of the students' context. Social research is not limited to the use of qualitative procedures, other techniques such as surveys provide quantitative data related to people's beliefs or opinions as in the case of written questionnaires or formal interviews which gather information on the backgrounds, behaviors, beliefs, or attitudes (Neuman 2014).

BARRAGÁN-DÍAZ, Julian. A study of student and teacher attitudes and experiences towards an immersion course in a Technological University in Veracruz, Mexico. Journal of Teaching and Educational Research. 2019 
For this reason, although this ethnographic research relies on a qualitative paradigm, a qualitative tool was used as the first tool to obtain data. The questionnaires followed a Likert scale format which is a common rating format for surveys to identify the underlying continuous variable that may show the respondents' opinions and attitudes (Allen \& Seaman, 2007).

The first step taken to collect data was applying a ten-item, questionnaire which included nine multiple choice questions and one open question to sixty-five students.). These students belonged to one group of the Industrial Maintenance program, one from International Trade program and one from the Information Technologies program. This in order to have a sample of students from each program although the questionnaire was anonymous and did not ask the name of the program they belonged to for avoiding any potential risk of the students nor answering honestly if their identity was made public. In spite of being designed in English, the questionnaire was printed and distributed in Spanish due to the fact that the students do not possess an advanced level of English and this could limit their participation in the case some questions were not fully understood.

In order to complement the information obtained from the interviews, some interviews were conducted among students and teachers since through conversations the researcher can have access to what people hear, experience and how they feel about the world in their own words and it is useful in this study for the reason that Kvale (1996) states: 'the qualitative research interview attempts to understand the world from the subjects' points of view, to unfold the meaning of peoples' experiences, to uncover their loved world prior to scientific explanations'.

The format chosen for this study was semi-structured because it was based on the questionnaire previously answered with the purpose of obtaining more detailed information from the participants in their own words. After the initial questionnaire was answered a total of ten participants - five students and five teachers - were asked to volunteer to do an interview which was audio recorded to be analyzed later.
The researcher did not participate as a teacher or worked with the groups in any form during this stage, the first contact with the students was when the class observations, the application of questionnaires and interviews took place.

While gathering data through questionnaires and interviews gave the researcher information about how students and teachers experience the immersion program and their feelings towards it, the researcher considered it important to see the classwork to be able to match what was expressed individually to the group dynamics. Observation are commonly done using notepads, a laptop, audio recorders and in some cases, photographs, however, regardless of the tool chosen for collecting information the methodological model is the same, what is seen and heard has to be quickly recorded and organized in a way that makes sense to the researcher. It is important to be aware that by doing this the exercise becomes a personal interpretation and, as a consequence, there is the risk of introducing a powerful bias especially if the researcher has strong preconceptions (Davies and Hughes, 2014).

The purpose for doing observations was to validate and enrich the data obtained from the questionnaires and interviews and in order to obtain more data related to the attitudes of the students and teachers. In order to do this two classes of the immersion program for students who need to reach the level A2 were observed. The researcher did not participate in class during the observations.

\section{Results}

Prior to the start of the immersion course all the students presented an entrance test to know their level of language proficiency and compare it to their level at the end of the program. Both exams applied are exams designed to measure language skills at an A2 level.

Although the results of the final exam show a tendency of students' improvement in the performance of an A2 exam these results are not $100 \%$ reliable since both the entrance exam and the final exam were different and elaborated by a different company. Some students mentioned this situation in their interviews as an element that contributed to a change in their attitude. 
Questionnaire results are displayed below in two charts that include the answers grouped into a common idea (bar graph 1).

In the first chart, forty-six participants declared their expectations had changed and gave a number of reasons that are shown in bar graph 1; the reason mentioned the most was that English was necessary for their studies and future career plans as well as two other reasons such as that they are aware that they increased their knowledge of the language and also that they considered it hard. The next most popular commentaries were three; first, the students stated that their expectations changed because they did not know the curricula of the programs they chose; second, the program was different to what they expected and finally they mentioned that the time assigned for achieving the objectives of the immersion course was short.

Other comments were related to the fact that some students changed their expectations because they originally thought only Spanish was necessary to have a good professional formation, however during the course they realized English was also important for reaching such goal. Finally, other individual commentaries were also mentioned as reasons such as the program being easier than expected, the chance for knowing the curriculum better, the satisfaction of having more effective study habits and the strong affinity towards the bilingual program which would make this student re-enroll next year in case of failing to achieve the objectives.

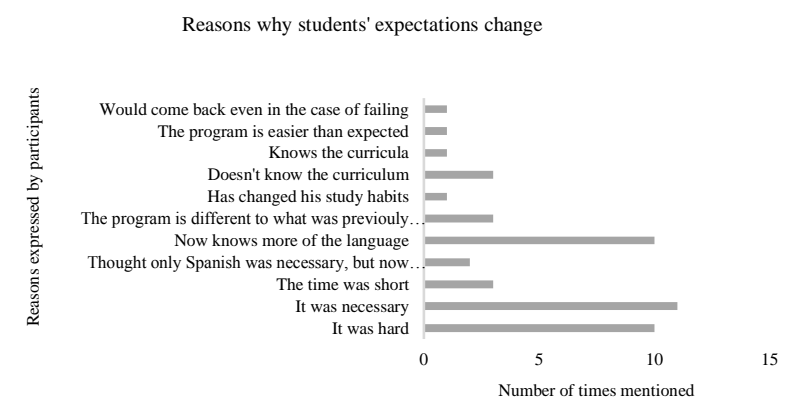

Graph 1

The second chart (bar graph 2), organized into four main categories, shows the comments of the 19 participants who said their expectations did not change after the immersion course.
It is important to note that not all students elaborated on the reason for stating that their expectations did not change, however most of the students responded that they knew the characteristics of the program, as a result, the immersion course and its requirements were not a surprise for them and were ready to face the challenges. Other students mentioned that they considered learning English an important part of their professional development and finally, other participants commented they expected the course to be difficult and they also were aware they needed to study harder.

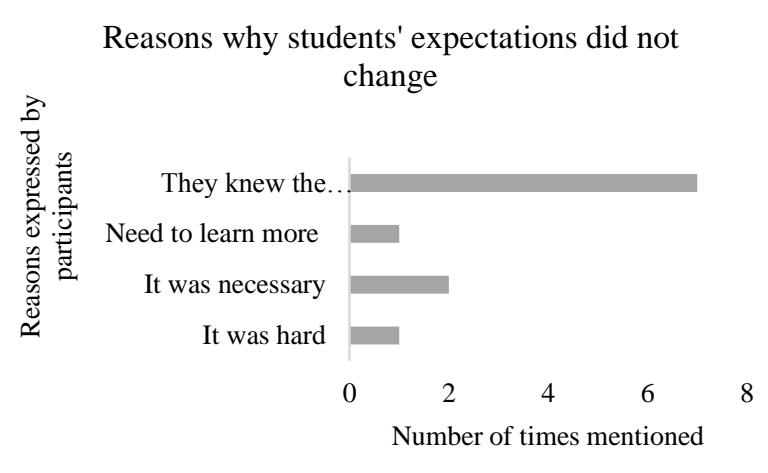

Graph 2

According to the results, the researcher implies the majority of students mentioned their expectations had changed because of inaccurate expectations they had towards the immersion program or the use of the language after the course; only few students reported being aware of what was expected from them. This may suggest it is important to set clear objectives from the beginning to help students focus on what they need in order to achieve such objectives.

Finally, although the results obtained in the questionnaires helped the researcher have a clearer idea of the attitudes and experiences of both students and teachers towards the immersion programs they are not conclusive in the sense that it is necessary to know more about the reasons behind their answers. A semistructured interview was used to obtain the qualitative data as it was previously mentioned. Ten participants were interviewed, four teachers and six students, all of them participants of the immersion course. One of the most common comments during the interviews were the rejection many students had towards English, some interviewees mentioned that they knew some students who were not interested in learning the language for a number of different reasons: they were not interested in the program. 
The objectives of the program did not match their personal objectives or their past experiences learning the language were not satisfactory nor productive.

Some of the teachers interviewed mentioned that students who were less interested in learning the language used Spanish regularly during classes even when asked to use English for basic functions such as asking for the meaning of unknown vocabulary or permission to go to the restrooms.

Although students were facing different difficulties throughout the course there were comments that the groups were friendly and generally helped each other for doing homework or to clarify doubts; however, being too close, in some cases, lead to problems such as organizing parties during the week affecting their performance during the course since these students started to skip classes and miss deadlines. Some participants mentioned this was closely related to alcoholism and also mentioned this had a negative impact on students' performance.

It was also mentioned that some students talked to the teachers about their will of not participating during the class either when asked why they did not want to participate or mentioned this to avoid being asked. One teacher mentioned that, based on his experience in the group he considered the students were afraid of speaking because they did not want to 'lose face'; he mentioned:

"... when they know automatically want to participate, then the guys at the front say ' $I$ know it, I know it, I want to pass! two or three times, no, now it's the time for the people in the back and there were three or four who never wanted to participate".

Participants commented they have observed this behavior and other problems related to self-esteem especially in students from small communities near cities.

The interviewees gave examples of some students whose self-esteem was low and preferred not to participate to avoid making a mistake in front of their classmates and being ridiculed. Arnold (2000) mentions that "our selfimage becomes more vulnerable when our expression is reduced to infantilized levels. This situation inevitably leads to anxiety."
Some of the teachers coincided on this matter by stating that, according to their experience, many students prefer not to be involved in class dynamics. This suggests that there are students in the immersion program that do not participate because they prefer to "save face" instead of making a mistake in front of the group. The researcher considers there is work to be done related to creating a relaxed atmosphere during the immersion course were all students feel confident and safe to participate to develop their language skills because in later trimesters the demands will be higher and these students may be left behind by the more advanced students.

One student mentioned during the interview that he had always had a problem in which he becomes very nervous before an examination and he felt this had a negative impact on his test result; he mentioned that he considers that since many students experience this in class, in presentations and during exams teachers think their level is lower but they are confident they know more although ignoring the causes of that.

Students and teachers commented they were aware of some students who achieved the desired level due to the fact that they were disciplined and organized regardless of their place of origin. It was noted that students tended to be quieter when spoken to only in English, and more open and participative when they have the chance to speak in Spanish as one participant mentioned:

"Sometimes they don't want to participate because they don't like it or because they are afraid to speak or learn it for fear of being laughed at or because they are lazy"

Based on this data the researcher considers these characteristics of some students represent a difficulty to achieve the objectives of the program since the students need to be involved during the course. One of the participants commented he had difficulty paying attention to the classes because some of his classmates were not interested and talked during class making it difficult for the others to concentrate, besides the small classroom did not allow him to move to another side of the classroom away from the distractors. 
One mentioned he considered himself autonomous since he regularly tried to work on his own at home but had difficulty finding appropriate material, he mentioned he could work on his grammar and writing but could not find listening exercises that help him develop. Based on experience the researcher finds this common; teachers most of the times are concentrated on covering the syllabus and rarely dedicate time to teach students skills to find the correct material according to their level which would leave them without a sense of achievement.

When asked about their opinions about how feasible it is for the students to achieve the desired level to start the program (A2) the participants commented that they believe such objective is attainable, however they are aware some factors would represent obstacles to reach the desired level; too many hours at school, tight deadlines, tutoring sessions in the afternoon besides household duties for those who come from other places and moved to the city. This leaves them with not enough time to rest and try to work on their language development in an autonomous form. The participants also mentioned that most of the students enrolled in the university felt excited in the beginning and during the first weeks were determined, this resulted in high attendance and participation but they started to feel tired during the following weeks for the reasons mentioned before and their initial motivation began to decrease; they noted that although most of the students felt tired they were still interested in the immersion course.

The data gathered shows evidence that academic stress influenced the attitudes of students during the immersion course as some students mentioned:

\section{"We are not used to pressure. It depends on the person... pressure can be something that pushes you to go after your objectives. Young people are used to obtain everything fast, like for example you need something, you go to Google and you can download anything"}

"(The course) finishes late and it is tiring when we go out. I would have more time to do homework, there is not enough time. Even some classmates that come to classes in the afternoon go out late and they don't have time, some of them travel. I guess I would have more time to rest and do my homework.
This evidence may suggest stress is one if the main factors affecting students' performance and one of the most common in schools as Misra (2000:41) claims: 'Students report experiencing academic stress at predictable times each semester with the greatest sources of academic stress resulting from taking and studying for exams, grade competition and the large amount of content to master in a small amount of time". In the author's opinion it is of utmost importance to consider the factors that are causing academic stress in the students of the immersion programs in the institution to help them achieve the desired objectives.

Although the results of the questionnaire and the answers of the interview showed that students felt they acquired enough knowledge about the language to start the programs they also mentioned they felt afraid of not increasing their level in the upcoming trimesters. The students interviewed knew the curriculum of the programs they chose and were aware that the number of subjects they would study in English would increase each trimester, for this reason they mentioned they felt their current level of English would not be enough. Another concern they mentioned was that they felt the time they had to achieve the level required at the end of the program might not be enough based on the amount of hours they spent to reach the A2 level and taking into consideration that they would have less hours of language instruction per week.

Also, during the interviews the researcher asked the students how much effort they thought their classmates were putting to achieve the same objectives and they mentioned that they considered many of their classmates were not making the necessary effort to do so. They mentioned they could observe that because some students were not interested in the class and listed some negative attitudes these students had towards the class such as: not paying attention to the teachers, talking to others during the presentation of topics, using the cellphone during class, not doing classwork or not handing in assignments.

Different participants coincided with the idea that an event that occurred during the second half of the trimester might have caused a notorious decline in some students' motivation and attitudes towards the program. 
According to the interviewees such event consisted on the following: at the beginning of the course, the students were informed they had to pass the A2 exam at the end of the course to be able to enroll to the first trimester of the program chosen, however they were informed later that those who did not pass the exam would be able to enroll in the monolingual program located at a different campus. The participants agreed that from that moment until the end of the immersion course they could observe that the students who were having difficulties with the language stopped working in and outside the classroom, although no details were asked about these students' identities the researcher was able observe students from two different classrooms who were not interested in the classes.

As a summary, according to the evidence it is possible to mention that there are a number of variables that affected the students' attitudes towards learning English, for instance: selfesteem, the amount of work and stress caused by school activities, and the changes in the school program. These situations seem particular of this university since it defines the profile of the students; also, because the students' response to these situations also vary it is important to be aware of the students' profile to anticipate any type of problems related to attitudes.

Other topics mentioned during the interviews were the reasons the students had for studying in the Technological University of Gutierrez Zamora were varied, they cited their own reasons as well as the others' reasons which helped them to decide to course a bilingual program in the university. The most mentioned reason was that students were interested in the bilingual programs because studying in a university which uses this model represents an opportunity for them to continue their studies abroad and it would give them the chance to get training or get a job in another country. Students who enrolled in the university for this purpose considered the university as their first option; however, others enrolled because they could not get a place in the university they chose first, one participant mentioned this was the case of a student who wanted to study medicine but since he could not enroll in that program he decided to try one of the bilingual programs, at the end of the immersion course this student decided not to continue.
This was not an isolated case, the participants mentioned, most of the students that seemed demotivated either enrolled in a traditional monolingual program or decided to look for a different university at the end of the immersion course. In spite of the situations mentioned previously, other participants mentioned many of their classmates chose one of the bilingual programs as their first option.

On the other hand, the participants also mentioned reasons why their classmates decided not to continue studying in the bilingual model, some cited the difficulty learning the language had represented to them and decided to avoid this problem in the future and study in another university where English is not required. Also, it was mentioned that some students who quit heard from other sources that learning English took many years in other schools and were disappointed when they knew they had to put an extra effort to achieve this in less time. Finally, the participants mentioned the case of some students that opted for finding another university due to family pressures. This data shows there were factors that affected their decisions that could not be controlled by the institution even if the student demonstrates being able to study in a bilingual model. The researcher considers the information about bilingual programs is complex and new in our Mexican context therefore it should be presented clearly to avoid students being disappointed during the program.

It was mentioned earlier that some students had difficulties finding time to do house and school activities after classes, during the interviews the participants added that some students already had a family and sometimes had a part-time job and these personal factors lead to these students feeling tired and with not enough time to dedicate to their studies. The participants mentioned this had a negative impact since these students cannot go to tutoring sessions in the afternoons nor look for help in case they need to work extra on a difficult topic. It is important to mention that the interviews revealed that a high number of students had difficulties attending classes and doing their assignments because of problems related to addictions, especially alcoholism. They mentioned that it is a common problem of students who come from other cities and live with friends. In the researcher's opinion, the students' personal problems represent a threat to the objectives of both the institution and the students since are not commonly discussed. 
During the interview the researcher also obtained information related to the students' performance in the final exam. The participants mentioned some characteristics they observed of those students who obtained the A2 level and some of those who did not obtain it. They mention most of the students who achieved the level had been consistently receiving good marks in their assignments and during the mock tests, on the other hand, most of the students who did not reach the level were students who had had attitude or personal problems during the course; they also mentioned isolated cases of students who were overconfident and did not prepare for the examination and failed as a consequence in spite of being aware they had the necessary abilities to pass the exam. Finally, one of the participants mentioned being nervous before the final exam and as a result, he failed to achieve the A2 level, this was disappointing because this student mentioned he had studied English before and felt he did not have to put much effort into reaching the objective.

The comments above have a close relation to the attitudes of the students, however, this time in terms of an overconfidence that affected the outcome of the exams. In the opinion the researcher this brings more evidence towards being clearer at the beginning of the immersion course about what students should expect from the bilingual program.

The participants expressed different concerns related to the course objectives, especially when comparing them to the duration of the program how feasible it is to achieve the goals established. The most repeated commentary was that although the immersion course is productive, the number of daily hours dedicated to study the language ( 5 to 8 ) is too high and leads to tiredness from the students who get frustrated when they find it difficult to concentrate during the last hours of class. Participants commented the following:

\section{"Eight hours of English everyday... the brain gets tired after two hours"}

"Students are here in the classroom but their minds are somewhere else. I don't see the point that they are here eight hours a day even if we play games or videos... even so, two hours are more than enough, it's tiring for the teacher and for the student".
These opinions are related to the attention span students have as Barnes et $\mathrm{Al}$ (2007) mention about recent generations of young adults called Net Geners.

It is important for educators to understand that, at least sometimes, when Net Geners complain that a particular subject seems unnecessary, they may not be expressing a lack of interest. Rather, the range of activities demanding the time and attention of young people may make them less patient with lessons that do not directly apply to their chosen careers. Multitasking, Net Geners claim, simply helps them get everything done. Whatever the motivation, educators must contend with the fact that multitasking is a way of life for many of today's students.

While the participants mention the time they spent at school made them feel tired the literature suggests there is a generation gap that teachers need to be aware of. In the researcher's opinion this does not mean that language courses need to be shorter but that all participants need to consider the characteristics of the people involved in the immersion course to plan the curricula according to their need taking into consideration factors such as the time inside the classroom and the characteristics of new generations as well as their attention span. Another frequent comment that was shared by students and teachers was that the difficulty of achieving the A2 level in four months makes them question the possibility of reaching such objective in what they consider a short period of time. These opinions were also mentioned when related to the objective of reaching a higher level at the end of the two-year programs.

All participants agreed with the idea that the objectives of reaching the A2 level at the end of the immersion course and obtaining a higher level at the end of the program were possible with discipline and hard work, nevertheless the duration of the course and the program respectively is too short and can be a major factor for not achieving the goals.

The teachers also commented that they felt it was normal to have students who are interested in studying a professional degree but not interested in learning a second language, thus the lack of motivation, the negative attitudes towards English and a certain dropout rate was expected. 
Finally, although most of the students interviewed mentioned they felt their level of English was satisfactory to start the bilingual program, some of them commented they did not feel confident about their command of the language to take classes in English.

When asked about how the course developed, the participants shared their thoughts about how the immersion course was planned and expressed that they considered the form the information was given might have had a negative impact in the students. They mentioned that there was an induction session were they were explained the characteristics of the bilingual model along with the details about costs, examinations, materials and enrollment options, however, most of them changed during the immersion program. The interviewees mentioned many students felt increasingly upset by that situation but decided to finish the immersion course. The participants stated those continuous changes in the course structure contributed to a change in the students' attitudes as well as changes that could be observed when the students stopped being concerned about the consequences of not working inside and outside the classroom.

A key point in this discussion is related to curricular development and program implementation. Both should take into account teachers and researchers to follow a bottom-up approach instead of top-down when developing the programs to avoid making decisions based on other but academic interests as Cummins and Davison in Davies (2009) claim: "Policies and practices relating to ELT are, unfortunately, just as likely to be motivated by political pressure backed up by plausible but flawed assumptions as they are by research and careful evaluation of alternative options".

Participants interviewed also expressed their concerns about the lack of organization in the programs for learning English in Mexico, this is according to the participants, programs in secondary school and high school start with A1contents and a consequence the students arrive at university levels with preconceptions about the language which are difficult to change, for example, excessive use of traditional methods, teachers with no professional training and materials designed for students who do not share the cultural background of Mexican students.
In the opinion of the researcher this is a common commentary from teachers in Mexico and not only in the area of the Technological University. Much work is needed to improve language teaching across all levels from elementary to high school.

\section{Observation Results}

Class observations were carried out in two classrooms of students who needed to achieve an A2 level. The researcher could observe that some students were not interested in the class because, in some cases, they did not have their material, in others were not paying attention to the instructions, were talking to others ignoring the activities to do and in some cases, some students seemed sleepy. This supports the comments made by teachers and students who stated that a small percentage of students were not interested in learning the language during the immersion course. The teacher tried to engage those students in the activities but they seemed reluctant to make an effort to do the activities; besides, in the moments when the teacher walked around the classroom monitoring and giving feedback on students' work the less interested students used this time to talk among themselves taking advantage of the teacher's distraction.

Based on the data gathered during the observations the researcher can mention that the conditions of the classrooms and the activities done inside the classroom were not a necessarily a factor that could affect students and teachers' attitudes during the immersion course. The university had the necessary infrastructure to achieve the goals established. On the other hand, the researcher could observe some students who showed their lack of interest for learning the language as well as some students who were actively engaged in the classroom activities.

\section{Conclusions}

The main objective of the research was to study the attitudes and experiences of students and teachers during the immersion course that precedes the first trimester of the new bilingual programs in the Technological University of Gutierrez Zamora. To study this, data from the entrance exam was gathered to compare it to the final examination results; this showed an improvement in the marks obtained by the students which represented the effectiveness of the course in terms of language development.

BARRAGÁN-DÍAZ, Julian. A study of student and teacher attitudes an experiences towards an immersion course in a Technological University in Veracruz, Mexico. Journal of Teaching and Educational Research 2019 
Then a questionnaire was applied to have an overview of the attitudes and experiences of students during the immersion course. Since this tool showed quantitative results it was necessary to make interviews to analyze qualitative data. Finally, some observations were carried out to validate the data from the previous steps. The data gathered suggested that students and teachers generally have a positive and optimistic view about the immersion course and about the bilingual programs, however there were a number of factors that affected the students' motivation and hence, attitudes. These factors included the characteristics of the students from the region, the personal motivations to study English, their reasons for enrolling in a bilingual program and the course planning and implementation.

\section{Implications for Students and Teachers}

Students would benefit from being more conscious of their reasons to study a certain program to avoid disappointments during their studies and ultimately spending time on something they will not finish. Teachers and school authorities, on the other hand, need to be aware of the students' characteristics and needs since programs designed for being used across Mexico may not work as effectively with students from the region. Also, teachers and authorities should work together on course design to help students have a clearer view of their studies and their expectations from the moment they enroll to the moment they graduate.

\section{Limitations}

This research intended to provide a look at the way students and teachers view immersion courses based on their experiences. This study was carried out during the first immersion program in a local university that is working to offer an alternative to traditional programs, this means that the results and suggestions given here may not apply to larger contexts or contexts with students with different characteristics. Besides, since the immersion program is arduous it was not always easy to have access to the participants who were busy in the immersion course

\section{Suggestions for Further Research}

This researcher has showed experiences of a sample group of students and teachers, further research would benefit from having a larger group of participants of the immersion courses as well as students and teachers of the following trimesters of the bilingual program in order to have a more complete view about how the programs are achieving their objectives.

\section{References}

Allen, E. and Seaman, C. (2007). "Likert Scales and Data Analyses". Quality Progress. pp. 64-65 retrieved from: http://asq.org/qualityprogress/2007/07/statistics/likert-scales-anddata-analyses.html

Ananyeva, M. (2013) A Learning Curriculum: Toward Student-Driven Pedagogy in the Context of Adult English for Academic Purposes, English for Specific Purposes, and Workplace English Programs. TESOL Journal. Volume 5, Issue 1, Version of Record online: 24 JAN 2013

Arnold, J. (2000). Speak Easy. How to Ease Students into Oral Production. Pilgrims Ltd.

Baker, C. (2001) Foundations of Bilingual Education and Bilingualism Third Edition MULTILINGUAL MATTERS LTD Clevedon

Barnes, K. et al. (2007)"Teaching and Learning with the Net Generation." Journal of Online Education. Vol. 3. No. 4. 2007 pp. 1-8.

Bhatia, T. and Ritchie, W. (2006). The Handbook of Bilingualism. Blackwell Publishing Ltd

Bell, J. (2010). Doing your Research Project. Open University Press

Brown, D. (2000) Principles of Language Learning and Teaching. Pearson Education

California State Dept. of Education (1984) Studies on Immersion Education.A Collection for United States Educators. California State Dept. of Education,Sacramento. Office of Bilingual Bicultural Education 
Cammarata, L. and Tedick, D. (2012) Balancing Content and Language in Instruction: The Experience of Immersion Teachers in the Modern Language Journal 96

Cohen, Manion \& Morrison (2007) Research Methods in Education. Routhledge London.

Cook, V. (2008) Second Language Learning and Language Teaching. Hodder Education, London.

Council of Europe (2001) Common European Framework Of Reference For Languages: Learning, Teaching, Assessment. Cambridge University Press

Cummins, J. (1998). Immersion education for the millennium: What have we learned from 30 years of research on second language immersion? In M. R. Childs \& R. M. Bostwick (Eds.) Learning through two languages: Research and practice. Second Katoh Gakuen International Symposium on Immersion and Bilingual Education. (pp. 34-47). Katoh Gakuen, Japan.

Davies, N \& Hughes, N. (2014) Doing a Successful Research Project. Palgrave Macmillan. New York

Davies, P. (2009). Strategic Management of ELT in Public Educational Systems: Trying to Reduce Failure, Increase Success. The Electronic Journal for English as a Second Language. December 2009 - Volume 13, Number 3

Flores Crespo, P. (2009) Trayectoria del Modelo de Universidades Tecnológicas en México (1991-2009) UNAM retrieved from: http://www.dgei.unam.mx/cuaderno3.pdf

Genesee, F. (1994) Integrating Language and Content: ${ }^{\circ}$ Lessons from Immersion. Educational Practice Reports. No 11. National Center for Research on Cultural Diversity and Second Language Learning. Washington, DC: Center for Applied Linguistics.

Griffith, W. I. Hye-Yeon L. (2014) Introduction to Competency-Based Language Teaching. MEXTESOL Journal, Vol. 38, No. 2, 2014. Special issue: Competency-Based Education in Mexico. Published: August, 2014 ISSN: 23959908
Holliday, A. (2002) Doing and Writing Qualitative Research Sage Publications, London.

INEGI (2010). Migración, Los que se van y los que llegan. Retrieved from: http://cuentame.inegi.org.mx/poblacion/migraci on.asp $x$ ?tema $=\mathrm{P}$

Jenkins, J. (2015) Global Englishes Third Edition. A resource book for students.

Routledge. London.

Jennifer L. O’Donoghue, J. (Editor) (2015) Sorry. Learning English in Mexico. Retrieved from

https://www.mexicanosprimero.org/images/stor ies/sorry/Sorry\%20English2015.pdf

Jiménez, I. (2015, June 29th) 27 empresas globales que más pesan en México. Forbes México. Retrieved from: http://www.forbes.com.mx/27-empresasglobales-que-mas-pesan-enmexico/\#gs.LxmKCBM

Kara, A. (2009). The Effect of a 'Learning Theories' Unit on Students' Attitudes towards Learning. Australian Journal of Teacher Education, 34(3), 100-113. Retrieved from: http://ro.ecu.edu.au/ajte/vol34/iss3/5

Kvale, S. (1996) Interviews. An Introduction to Qualitative Research Interviewing' Sage Publications USA

Nation, I.S.P. \& Macalister, J. (2010) Language Curriculum Design. Routledge. New York

Misra, R. (2000). College students' academic stress and its relation to their anxiety, time management, and leisure satisfaction. American journal of health studies 16(1):41-51 January $2000 . \quad$ retrieved from https://www.researchgate.net/publication/20983 5950_College_students'academic_stress_and_it s_relation_to_their_anxiety_time_management _and_leisure_satisfaction

Neuman, W.L. (2014) Social Research Methods: Qualitative and Quantitative Approaches. Pearson Essex.

No author (2012). International Standard Classification of Education ISCED 2011. UNESCO Institute for Statistics. Montreal, Canada. Obtained from

BARRAGÁN-DÍAZ, Julian. A study of student and teacher attitudes an experiences towards an immersion course in a Technological University in Veracruz, Mexico. Journal of Teaching and Educational Research. 2019 
Pérez, M.S., Bellaton, P, and Emilsson, E (2012). "La enseñanza de lenguas en México. Hacia un enfoque plurilingüe" Revista Universitaria, 10, August 30, 2012, National Pedagogic University. Retrieved from: http://www.uaa.mx/direcciones/dgdp/defaa/des cargas/ensenanza_de_lenguas.pdf

PIPIA, Ekaterine. (2013) The history and nature of immersion programs in American context. Journal of Education; ISSN 2298-0172

Reyes, I. (2012) Biliteracy Among Children and Youths. Reading Research Quarterly • 47(3) • pp. 307-327

Richards, J. (2013) Curriculum Approaches in Language Teaching: Forward, Central, and Backward Design RELC Journal Vol 44, Issue 1, pp. 5 - 33 First published date: March-112013

Roberts, C. (1995) BILINGUAL EDUCATION PROGRAM MODELS: A FRAMEWORK FOR UNDERSTANDING. THE BILINGUAL RESEARCH JOURNAL. Summer/Fall 1995, Vol. 19, Nos. 3 \& 4, pp. 369-378

Sayer, P. (2015) A Response to the Sorry Report on the State of the PNIEB and English Language Education in Mexican Public Schools. MEXTESOL Journal, Vol. 39, No. 4, 2015

Seidlhofer, B. (2009) Common ground and different realities: world Englishes and English as a lingua franca. World Englishes, Vol. 28, No. 2, pp. 236-245, 2009.

SEP (Secretaría de Educación Pública). (2016). Comunicado 533 Universidades Tecnológicas y Politécnicas con Modelo BIS responden a demanda global de profesionistas de calidad. Retrieved from: https://www.gob.mx/sep/prensa/comunicado533-universidades-tecnologicas-y-politecnicascon-modelo-bis-responden-a-demanda-globalde-profesionistas-de-calidad?idiom $=$ es http://www.uis.unesco.org/Education/Documen ts/isced-2011-en.pdf

Swain, M., \& Johnson, R. K. (1997). Immersion education: A category within bilingual education. InR. K. Johnson \& M. Swain (Eds.), Immersion education: International perspectives (pp. 1-16). New York: Cambridge University Press.
Vaish, V. (2008) Biliteracy and Globalization English Language Education in India.

Multilingual Matters ltd. 